\title{
Risk compensation and bicycle helmets : A false conclusion and uncritical citations
}

\section{Radun, Igor}

2018-10

Radun , I , Radun , J , Esmaeilikia , M \& Lajunen , T 2018 , ' Risk compensation and bicycle helmets : A false conclusion and uncritical citations ', Transportation Research. Part F:

Traffic Psychology and Behaviour, vol. 58 , pp. 548-555 . https://doi.org/10.1016/j.trf.2018.06.038

http://hdl.handle.net/10138/310074

https://doi.org/10.1016/j.trf.2018.06.038

cc_by_nc_nd

acceptedVersion

Downloaded from Helda, University of Helsinki institutional repository.

This is an electronic reprint of the original article.

This reprint may differ from the original in pagination and typographic detail.

Please cite the original version. 
Radun, I., Radun, J., Esmaeilikia, M., \& Lajunen, T. (2018). Risk compensation and bicycle helmets: A false conclusion and uncritical citations. Transportation Research Part F: Traffic Psychology and Behaviour, 58, 548-555. https://doi.org/10.1016/j.trf.2018.06.038

Title: Risk compensation and bicycle helmets: A false conclusion and uncritical citations

Igor Radun, ${ }^{1,2} \mathrm{PhD}$

Jenni Radun, ${ }^{3} \mathrm{PhD}$

Mahsa Esmaeilikia, ${ }^{4} \mathrm{PhD}$

and Timo Lajunen, ${ }^{4} \mathrm{PhD}$

1 Department of Psychology and Logopedics, Faculty of Medicine, University of Helsinki, Finland

2 Stress Research Institute, Stockholm University, Sweden

3 Turku University of Applied Sciences, Turku, Finland

4 School of Mathematics and Statistics, University of New South Wales, Australia

5 Department of Psychology, Norwegian University of Science and Technology (NTNU),

Trondheim, Norway

Corresponding author: Igor Radun, Department of Psychology and Logopedics, Faculty of Medicine, University of Helsinki, Finland

Tel.: +358 2941 29417; E-mail address: igor.radun@helsinki.fi Home page:

http://www.mv.helsinki.fi/home/radun

Disclosure Statement: No significant financial interest or other relationship to disclose. 
Radun, I., Radun, J., Esmaeilikia, M., \& Lajunen, T. (2018). Risk compensation and bicycle helmets: A false conclusion and uncritical citations. Transportation Research Part F: Traffic Psychology and Behaviour, 58, 548-555. https://doi.org/10.1016/j.trf.2018.06.038

\section{Abstract}

Some researchers and many anti-helmet advocates often state that when cyclists wear a helmet they feel safer and take more risks. This hypothesis - risk compensation - if true, would reduce, annul or even reverse the assumed benefits of helmets in reducing head injuries. Consequently, this hypothesis is often used to oppose mandatory helmet laws. In this article, we illustrate how one of the few studies that attempted to experimentally test the hypothesis in relation to bicycle helmets arrives at a false conclusion. As a result it is often cited as evidence of risk compensation. Given the lack of experimental studies in this research area, the impact of a single study in shaping the opinions of the general public and of policy makers can be significant.

Key words: Risk taking; Behavioral adaptation; Cycling; Risk homeostasis 
Radun, I., Radun, J., Esmaeilikia, M., \& Lajunen, T. (2018). Risk compensation and bicycle helmets: A false conclusion and uncritical citations. Transportation Research Part F: Traffic Psychology and Behaviour, 58, 548-555. https://doi.org/10.1016/j.trf.2018.06.038

\section{INTRODUCTION}

It has often been suggested that the effectiveness of bicycle helmets in reducing head injuries might be offset by risk compensation. This is a hypothesis that asserts that people have a homeostatic approach to risk taking such that any effort to improve safety is countered by greater risk taking (Wilde, 1998). In the case of cyclists it assumed that wearing a helmet would result in more risky riding (Robinson, 1996). Although there is no strong evidence supporting this hypothesis (Pless, 2016; Thompson, Thompson, \& Rivara, 2001) it has become one of the most frequent and strongest 'arguments' anti-helmet advocates use when they oppose mandatory helmet laws or the widespread promotion of bicycle helmets (see, for example, Cyclists' Rights Action Group website, 2017).

A literature search conducted in 2014 with the phrases "risk compensation" and "bicycle helmet" produced one article in Medline, nine using Scopus and six for Web of Science (Olivier et al., 2014). The authors stressed that four of the nine articles identified in Scopus were opinion pieces, not empirical studies. Our own brief search in Scopus in April 2017 using the same phrases found only eleven articles. This lack of studies on the issue obviously leaves wide latitude for speculation without the need for cherry-picking, which is the typical strategy various advocates groups use in promoting their own views and interests.

Such a lack of studies on an issue also means that the impact of a single study can be significant. How far this influence can go is illustrated by the case of a single-paragraph letter to the editor of the New England Journal of Medicine (NEJM) in 1980, which was "heavily and uncritically cited as evidence that addiction was rare with long-term opioid therapy" (Leung et al., 2017). This caused the authors of this recent analysis to believe that "this citation pattern contributed to the North American opioid crisis by helping to shape a narrative that allayed prescribers' concerns about the risk of addiction associated with long-term opioid therapy" (Leung et al., 2017). 
In this paper, we demonstrate how one of the rare experimental studies aimed at studying risk compensation and bicycle helmets arrives at a false conclusion (Messiah et al., 2012). It is, nevertheless, cited as evidence that helmeted (male) cyclists take more risks while riding a bike compared with those who ride without a helmet. Although we focus on a single study whose conclusion is in our opinion incorrect, our aim is to elicit discussion regarding the quality of research evidence and the way the research community deals with questionable conclusions.

After describing the study we offer arguments why we believe its conclusion is false. We then examine studies that cite the study and analyze in what context these citations have been made. Finally, we offer some general remarks about the potential consequences of false conclusions and uncritical citations.

\section{A CRITICAL ANALYSIS OF MESSIAH ET AL. (2012)}

\subsection{Summary of the study}

This study, "Risk Compensation: A Male Phenomenon? Results from a Controlled Intervention Trial Promoting Helmet Use Among Cyclists," argues that "risk compensation, observed only among male cyclists, was moderate, thus unlikely to offset helmet preventive efficacy" (Messiah et al., 2012, p.204).

To fully understand the methods used in Messiah et al.'s study, it was necessary to consult another publication (Constant et al., 2012) from the same naturalistic experiment. In this randomized controlled study, the authors recruited 1,798 participants in Bordeaux, France (June 2009 to August 2010) during a promotional campaign that allowed cyclists to borrow a bicycle for exclusively personal use for at least four months. The participants were randomly assigned to one of four 
Radun, I., Radun, J., Esmaeilikia, M., \& Lajunen, T. (2018). Risk compensation and bicycle helmets: A false conclusion and uncritical citations. Transportation Research Part F: Traffic Psychology and Behaviour, 58, 548-555. https://doi.org/10.1016/j.trf.2018.06.038

groups. One group received only a brochure promoting helmet use, another received a free helmet, the third were given both the brochure and helmet, while the fourth did not receive anything and served as controls. Those who reported previous helmet use $(n=241)$ were excluded from further analysis.

The main focus in Messiah et al.'s study was on the relationship between helmet wearing and the speed of cyclists as recorded by pairs of cameras stationed in five sites in the urban center of Bordeaux. Altogether 587 cyclists were observed in 2,621 situations. Identification was based on a unique color code placed on the bicycle's rear mudguard. The assumption was that only the recruited participants rode a given bicycle during the data collection period as only those who promised to use a bicycle for their own exclusive use were given a bike.

Helmets were observed in only $3.8 \%$ of the situations. Most helmet observations (84/99) came from the two groups that had received free helmets (Constant et al., 2012). Males rode slightly faster than females $(16.9 \mathrm{~km} / \mathrm{h}$ vs. $16.1 \mathrm{~km} / \mathrm{h})$, while a difference between helmeted and unhelmeted cyclists was observed only among males (251 participants, 1,172 observations, a helmet used in $5.1 \%$ of observations). The helmeted cyclists rode faster $(19.2 \mathrm{~km} / \mathrm{h}$ vs. $16.8 \mathrm{~km} / \mathrm{h})$. Besides helmet wearing, factors associated with speed among men included the age of the cyclist, the observation site, and the interaction between helmet wearing and the observation site.

The article's main conclusions are: "risk compensation is a male behavior;" "risk compensation tended to vanish as objective risk of injury increased, suggesting that it is subject to a ceiling effect;" "helmet use did not result in increased risk-taking among female cyclists;" and "risk compensation is limited and unlikely to offset the protective effect of helmet use" (Messiah et al., 2012, p.205). 
Radun, I., Radun, J., Esmaeilikia, M., \& Lajunen, T. (2018). Risk compensation and bicycle helmets: A false conclusion and uncritical citations. Transportation Research Part F: Traffic Psychology and Behaviour, 58, 548-555. https://doi.org/10.1016/j.trf.2018.06.038

These conclusions are surprising. In our view, the most troubling conclusion of this study is the attribution of the observed difference in speed between helmeted and unhelmeted male cyclists to (moderate) risk compensation. In the following section we address the shortcomings of the study and offer more general discussion about bicycle helmets and risk compensation.

\subsection{Critical analysis}

Three groups of cyclists were possibly observed in the study. These numbers include both men and women)

1. No helmet group. These are cyclists only observed without a helmet: 548 (587-39) cyclists with an unknown (to us) number of observations, but up to 2522 (2621-99).

2. Both helmet and no helmet group. This group contains cyclists observed at least once with a helmet and once without a helmet: up to 39 cyclists with an unknown (to us) number of observations with a helmet, but up to 99 , and an unknown (to us) number of observations without a helmet, but up to 1974 (2522-548).

3. Only helmet group. This group would represent those observed only with a helmet: up to 39 cyclists with an unknown (to us) number of observations, but up to 99.

\subsubsection{The lack of baseline data}

Theoretically, it is possible that there were no or only a few cyclists in group 2, which would mean that following the intervention most of the cyclists belonged in two very different groups (never vs. always observed riding with a helmet). In this case, it is possible that the pre-intervention riding speed/style was related to the helmet adoption, and thus the observed differences in riding speed between helmeted and unhelmeted cyclists would be no indication of increased risk taking. 
Radun, I., Radun, J., Esmaeilikia, M., \& Lajunen, T. (2018). Risk compensation and bicycle helmets: A false conclusion and uncritical citations. Transportation Research Part F: Traffic Psychology and Behaviour, 58, 548-555. https://doi.org/10.1016/j.trf.2018.06.038

To illustrate the mechanism of how pre-intervention riding style could be related to helmet adoption, consider the following example. We approach cyclists who normally do not wear a helmet. We give them a free helmet and a brochure emphasizing the relationship between speed and injury risk. Some of those who normally ride at higher speeds reason "perhaps it would be a good idea if I take a helmet next time I go for a ride.” The majority of those who ride at low speeds, however, conclude that they do not need a helmet because they ride at "safer" speeds. We follow our participants and observe that those few who adopt a helmet ride somewhat faster than those without a helmet. We conclude that we observed risk compensation, while in fact none of these hypothetical cyclists actually changed their speed following our intervention. Whether this indeed happened in Messiah et al. is impossible to know; however, there is no reason to discard this possibility.

Even if one argued that this example would fall within the domain of risk compensation if the perceived level of risk has changed with helmet adoption, we know nothing about the possible change in perceived risk in the Messiah et al. study. Furthermore, the authors repeatedly write about "speed increase" and "increased risk-taking" and not about deciding to wear a helmet to compensate for the unacceptably high perceived baseline level of risk.

\subsubsection{Type of trip and helmet wearing}

On the other hand, it is theoretically also possible that most of the cyclists observed riding with a helmet were also observed riding without a helmet at least once. In this case, the repeated measures approach applied in the statistical analysis was justified as the same people served as controls for themselves. However, the question that arises here is who these people were and why they sometimes rode with a helmet and sometimes without it. Obviously they did not randomly take a helmet (as in an experiment) and acted in accordance with the risk compensation: if it happens that I 
Radun, I., Radun, J., Esmaeilikia, M., \& Lajunen, T. (2018). Risk compensation and bicycle helmets: A false conclusion and uncritical citations. Transportation Research Part F: Traffic Psychology and Behaviour, 58, 548-555. https://doi.org/10.1016/j.trf.2018.06.038

take a helmet, I will ride faster, but if for some reason I do not take it with me, I will ride slower.

Was a decision to take a helmet with them a random one or did it have to do with the type of trip they were planning that day or for some other reason?

To further elaborate on this argument, the following example can be offered. Imagine a male cyclist riding to work. He doesn't ride fast because he doesn't want to get sweaty before he starts work. As he usually rides slowly to work, he doesn't wear a helmet. During the weekend (note that cameras "collected data 6 hours a day, 7 days a week" in the Messiah et al. study), he goes for a longer recreational ride. As he knows he will ride longer and faster than usual, he decides to wear a helmet. It is well known that whether one wears a helmet or not often depends upon the type of trip taken.. For example, in Rochester, Minnesota, US, adults riding longer durations were more likely to wear a helmet (Finnoff et al., 2001). Another example comes from the Netherlands, where the overall wearing of helmets is very low, but it is higher among those who go for recreational trips involving longer exercise (Willamor, Hammer, \& Martinez-Olaizola, 2008). So we might ask what came first: the chicken (the speed) or the egg (the helmet)? Does the fact that wearing a helmet makes one ride faster, or is it that helmets are worn when one goes on longer trips at higher speeds? It again needs to be pointed out that in only $5.1 \%$ of the observations in the Messiah et al. study did male cyclists wear a helmet. This is a very low figure, and it is highly likely that it represents a special group of people and trips not taken into account in the analysis.

\subsection{3. "Reverse risk compensation"}

The authors write (p. 205) "Because this study was conducted among new helmet users, reverse causality is unlikely to be at play." We are not fully sure what did they mean here but it might be that they referred to the so-called reverse risk compensation, according to which accustomed helmet 
Radun, I., Radun, J., Esmaeilikia, M., \& Lajunen, T. (2018). Risk compensation and bicycle helmets: A false conclusion and uncritical citations. Transportation Research Part F: Traffic Psychology and Behaviour, 58, 548-555. https://doi.org/10.1016/j.trf.2018.06.038

users would ride slower when they ride without a helmet. It has been shown in one experimental field study that cyclists who were regular helmet users cycled more slowly and reported more insecurity when cycling without a helmet than when using their own helmet (Phillips, Fyhri, \& Sagberg, 2011). However, we are not sure why a reverse risk compensation explanation should be discarded in Messiah et al. study given that it is unknown how long it takes for a person to get accustomed to a helmet. Does it take weeks, months or perhaps years? It should not be forgotten that the helmet rate was about 5 times higher in the first 139 days of data collection than during the remaining period (see Figure 3, Constant et al., 2012), which leaves the possibility that some cyclists got accustomed to a helmet during the first 139 days and then were actually riding slower during the last period when for some reason they decided not to wear it anymore. Regardless of how unlikely this might be, we see no reason why temporal ordering was not considered in the analysis.

We would like to make it clear here that the evidence of an effect in one direction (i.e., taking a helmet off leads to slower riding) does not mean the opposite effect (i.e., adopting helmet use leads to faster riding) must also be true. Making such conclusion would represent a type of logical fallacy (i.e., affirming the consequent) (Olivier, Esmaeilikia, \& Grzebieta, in press).

\subsubsection{Cycling speed as an indicator of risk taking}

This is a minor comment, but it still needs to be mentioned. Although risk taking is indeed sometimes operationalized as driving or riding speed, especially in situations where speed limits are seriously exceeded, there is no reason why a difference in speed of $2.4 \mathrm{~km} / \mathrm{h}(19.2 \mathrm{~km} / \mathrm{h} \mathrm{vs}$. $16.8 \mathrm{~km} / \mathrm{h}$ ) should be considered a sign of increased risk taking. This is especially troubling because the authors themselves write (p. 205) "the average speed at the fastest site was less than half the limit." Similarly, the authors considered "objective risk of injury" to be higher in sites with a higher average speed. It is not clear here whether it was assumed that the higher the (average) speed, the 
Radun, I., Radun, J., Esmaeilikia, M., \& Lajunen, T. (2018). Risk compensation and bicycle helmets: A false conclusion and uncritical citations. Transportation Research Part F: Traffic Psychology and Behaviour, 58, 548-555. https://doi.org/10.1016/j.trf.2018.06.038

higher the risk of injury in the case of a crash, or the higher the (average) speed, the higher the risk of a crash, or both. In any case, the assumption is at least unclear if not also unsubstantiated.

\subsubsection{Conclusion}

Because no baseline data were collected on cycling speed in the Messiah et al. study, it was not possible to estimate changes in cycling speed for those who adopted helmet use or for those who did not. Thus, based on the data they collected and the statistical modeling, at best Messiah et al. could say that because they were unable to control several important factors (e.g., the type of trip), did not check the possibility of the effect in the opposite direction, and did not have baseline data, they can only hypothesize that the results represent risk compensation. Unfortunately, the authors wrongly interpreted their results and continue to do so in later publications (see study 2 in Table 1; Felonneau et al., 2013).

\section{HOW MANY TIMES AND IN WHAT CONTEXT HAS THIS STUDY BEEN CITED?}

We performed a search in Google Scholar, Scopus and Web of Science for studies that had cited Messiah et al.'s (2012) study. The search was independently performed by two researchers (IR \& JR) in April 2017, and both of them identified the same number of citations: 21 in Google Scholar, 13 in Scopus and 12 in Web of Science. After excluding duplicates and two citations that were not actual publications, we ended up with 20 citations. Both authors then, again independently, read twenty publications and extracted relevant sentences and provided comments. The sentences extracted were identical, and the authors together compared and discussed their comments and agreed upon the final version shown in Table 1. 
Radun, I., Radun, J., Esmaeilikia, M., \& Lajunen, T. (2018). Risk compensation and bicycle helmets: A false conclusion and uncritical citations. Transportation Research Part F: Traffic Psychology and Behaviour, 58, 548-555. https://doi.org/10.1016/j.trf.2018.06.038

Fifteen publications cited Messiah et al.'s study as evidence of risk compensation (studies 1, 2, 5-7, 10-14, and 16-20 in Table I). Two publications cited Messiah et al. in other than a risk compensation context (study 8 mentioned that speed was used as a measure of risk, and study 15 mentions it in terms of low prevalence of helmet use). In one study (4) we were not fully sure how to interpret the citation. In only two studies ( 3 and 9) was the study cited negatively. One of these (9) states that the study did not find "clear evidence supportive of risk compensation," while the other (3) uses the word "speculation" in relation to possible occurrence risk compensation.

\section{FINAL REMARKS}

Our analysis suggests that a number of authors, including those of the Messiah et al. study, have easily jumped to incorrect conclusions about risk compensation and bicycle helmets. Interestingly, in our report published in Finnish we (I. Radun and Lajunen) made the same mistake as we also cited the Messiah et al. study as evidence that men increase riding speed if they wear a helmet (Lajunen, Kaistinen, \& Radun, 2015). For some reason our report was not identified in the literature search we performed in this study.

Even though the authors of the original study considered the effect to be moderate and "unlikely to offset helmet preventive efficacy," the fact that an inaccurate conclusion is uncritically cited in other publications is cause for concern. In the absence of experimental studies directly examining this phenomenon, the impact of a single study on the opinions of the general public and of policy makers can be significant. A single-paragraph letter to the editor of the NEJM is a clear example of that (Leung et al., 2017). We further emphasize that the Messiah et al. study does not discuss a theoretical or marginal issue, as millions of people around the world might make a decision whether to wear or not wear a bicycle helmet based on such rare but widely publicized studies. 
Radun, I., Radun, J., Esmaeilikia, M., \& Lajunen, T. (2018). Risk compensation and bicycle helmets: A false conclusion and uncritical citations. Transportation Research Part F: Traffic Psychology and Behaviour, 58, 548-555. https://doi.org/10.1016/j.trf.2018.06.038

While we wait and call for more rigorous studies to examine possible risk compensation among those who voluntarily choose (and/or are 'forced' by legislation) to wear a bicycle helmet, we urge other researchers to stop citing Messiah et al. (2012) as evidence of risk compensation. However, we are not very optimistic that this will actually happen, knowing that even retracted publications continue to be cited and in a positive context (Bar-Ilan \& Halevi, 2017). As Thomasson and Stanley (1955, p.611) wrote more than seventy years ago, "Buried in scholarly journals, critical notes are increasingly likely to be overlooked with the passage of time, while the studies to which they pertain, having been reported more widely, are apt to be rediscovered.” Unfortunately, this quote is still relevant despite the existence of numerous electronic databases.

\section{Acknowledgements.}

This study has not received direct funding, although it was carried out within the project on cyclist crashes partly supported by the Finnish Crash Data Institute (OTI), Finland with a personal grant to IR. The funders had no role in the conception or writing of this article. The authors thank Professor Emeritus Barry Pless for his valuable comments and suggestions on an earlier draft of this paper.

The authors also thank several researchers who commented on a preprint version of this manuscript posted on the first author's ResearchGate profile.

\section{REFERENCES}

Billot-Grasset, A. (2015). Typologie des accidents corporels de cyclistes ages de 10 ans et plus: un outil pour la prevention (Doctoral dissertation). Lyon, France: Universite Claude Bernard.

Constant, A., Messiah, A., Felonneau, M. L., \& Lagarde, E. (2012). Investigating Helmet Promotion for Cyclists: Results from a Randomised Study with Observation of Behaviour, Using a Semi-Automatic Video System. Plos One, 7. http://dx.doi.org/10.1371/journal.pone.0031651 
Cyclists' Rights Action Group Web site. "Five ways wearing a bicycle helmet can result in injuries.” http://crag.asn.au/category/helmets. Accessed June 26, 2017.

Felonneau, M. L., Causse, E., Constant, A., Contrand, B., Messiah, A., \& Lagarde, E. (2013). Gender stereotypes and superior conformity of the self in a sample of cyclists. Accident Analysis and Prevention, 50, 336-340. http://dx.doi.org/10.1016/j.aap.2012.05.006

Finnoff JT, Laskowski ER, Altman KL, Diehl NN. Barriers to Bicycle Helmet Use. Pediatrics. 2001; 108:e4.

James, J.E. (2015). The Health of Populations beyond Medicine. London: Elsevier.

Kett, P., Rivara, F., Gomez, A., Kirk, A. P., \& Yantsides, C. (2016). The Effect of an All-Ages Bicycle Helmet Law on Bicycle-Related Trauma. Journal of Community Health, 41, 1160-1166. http://dx.doi.org/10.1007/s10900-016-0197-3

Lajunen, T., Kaistinen, J, Radun, I. (2015). Pyöräilykypärän vaikutus pyöräilijän turvallisuuteen ja pyöräilyyn - kirjallisuuskatsaus [The impact of a bicycle helmet on cycling safety and cycling - a literature review]. Liikenneturvan selvityksiä 4/2015.

Li, J. L., Hajimirsadeghi, H., Zaki, M. H., Mori, G., \& Sayed, T. (2014). Computer Vision Techniques to Collect Helmet-Wearing Data on Cyclists. Transportation Research Record (2468), 1-10. http://dx.doi.org/10.3141/2468-01 
Radun, I., Radun, J., Esmaeilikia, M., \& Lajunen, T. (2018). Risk compensation and bicycle helmets: A false conclusion and uncritical citations. Transportation Research Part F: Traffic Psychology and Behaviour, 58, 548-555. https://doi.org/10.1016/j.trf.2018.06.038

Leung, P. T. M., Macdonald, E. M., Stanbrook, M. B., Dhalla, I. A., \& Juurlink, D. N. (2017). A 1980 Letter on the Risk of Opioid Addiction. New England Journal of Medicine, 376, 2194-2195. http://dx.doi.org/10.1056/NEJMc1700150

Lundberg, M., Shapira, G. (2014). Determinants of risky behavior. In: D. de Walque (Eds.), Risking Your Health Causes, Consequences, and Interventions to Prevent Risky Behaviors (pp. 37-69).

Washington, D.C.: The World Bank.

Messiah, A., Constant, A., Contrand, B., Felonneau, M. L., \& Lagarde, E. (2012). Risk

Compensation: A Male Phenomenon? Results from a Controlled Intervention Trial Promoting Helmet Use among Cyclists. American Journal of Public Health, 102, S204-S206. http://dx.doi.org/10.2105/Ajph.2012.300711

Olivier, J., \& Creighton, P. (2017). Bicycle injuries and helmet use: a systematic review and metaanalysis. International Journal of Epidemiology, 46(1), 278-292.

http://dx.doi.org/10.1093/ije/dyw153

Olivier, J., Esmaeilikia, M., \& Grzebieta, R. (in press). Bicycle Helmets: Systematic Reviews on Legislation, Effects of Legislation on Cycling Exposure, and Risk Compensation. Trafikverket.

Olivier, J., Terlich, F. (2016). The use of propensity score stratification and synthetic data to address allocation bias when assessing bicycle helmet effectiveness. 2016 IRCOBI Conference Proceedings - International Research Council on the Biomechanics of Injury, 185-193. 
Radun, I., Radun, J., Esmaeilikia, M., \& Lajunen, T. (2018). Risk compensation and bicycle helmets: A false conclusion and uncritical citations. Transportation Research Part F: Traffic Psychology and Behaviour, 58, 548-555. https://doi.org/10.1016/j.trf.2018.06.038

Olivier, J., Wang, J.J.J., Walter, S., Grzebieta, R. (2014). Anti-helmet arguments: lies, damned lies and flawed statistics. Journal of the Australasian College of Road Safety, 25, 10-23.

Olivier, J., Walter, S.R. (2013). Bicycle Helmet Wearing Is Not Associated with Close Motor Vehicle Passing: A Re-Analysis of Walker, 2007. Plos One. 8:e75424.

https://doi.org/10.1371/journal.pone.0075424

Osorio, A., Lopez-del Burgo, C., Ruiz-Canela, M., Carlos, S., \& de Irala, J. (2015). Safe-sex belief and sexual risk behaviours among adolescents from three developing countries: a cross-sectional study. Bmj Open, 5. https://doi.org/10.1136/bmjopen-2015-007826

Peachey, A. A., Sutton, D. L., \& Cathorall, M. L. (2016). Helmet ownership and use among skateboarders: Utilisation of the Health Belief Model. Health Education Journal, 75, 565-576. https://doi.org/10.1177/0017896915607912

Pless, B. (2016). Risk Compensation: Revisited and Rebutted. Safety, 2:16. http://dx.doi.org/10.3390/Safety2030016

Prati, G., Pietrantoni, L., \& Fraboni, F. (2017). Using data mining techniques to predict the severity of bicycle crashes. Accident Analysis and Prevention, 101, 44-54.

https://doi.org/10.1016/j.aap.2017.01.008

Richard, J. B., Thelot, B., \& Beck, F. (2013). Evolution of bicycle helmet use and its determinants in France: 2000-2010. Accident Analysis and Prevention, 60, 113-120. https://doi.org/10.1016/j.aap.2013.08.008 
Richard, J. B., Thelot, B., \& Beck, F. (2013). Les accidents en France : e'volution et facteurs associe's [Injuries in France: Trends and risk factors]. Revue d'E' pide'miologie et de Sante' Publique. 61, 205-212. https://doi.org/10.1016/j.respe.2012.10.007

Robinson, D. L. (1996). Head injuries and bicycle helmet laws. Accident Analysis and Prevention, 28, 463-475. http://dx.doi.org/10.1016/0001-4575(96)00016-4

Teschke, K., Koehoorn, M., Shen, H., \& Dennis, J. (2015). Bicycling injury hospitalisation rates in Canadian jurisdictions: analyses examining associations with helmet legislation and mode share. Bmj Open, 5. http://dx.doi.org/10.1136/bmjopen-2015-008052

Thomasson, P., Stanley, J.C. (1955). Uncritical citation of criticized data. Science. 121 (3147): 610611. http://dx.doi.org/10.1126/science.121.3147.610

Thompson, D. C., Thompson, R. S., \& Rivara, F. P. (2001). Risk compensation theory should be subject to systematic reviews of the scientific evidence. Injury Prevention, 7, 86-88. http://dx.doi.org/10.1136/ip.8.2.e1

Thomson, C. J., \& Carlson, S. R. (2015). Increased patterns of risky behaviours among helmet wearers in skiing and snowboarding. Accident Analysis and Prevention, 75, 179-183. http://dx.doi.org/10.1016/j.aap.2014.11.024 
Radun, I., Radun, J., Esmaeilikia, M., \& Lajunen, T. (2018). Risk compensation and bicycle helmets: A false conclusion and uncritical citations. Transportation Research Part F: Traffic Psychology and Behaviour, 58, 548-555. https://doi.org/10.1016/j.trf.2018.06.038

Treibich, C. (2014). Four Essays on the Economics of Road Risks in India (Doctoral dissertation.

International Institute of Social Studies of Erasmus University Rotterdam, Rotterdam, the Netherlands.

Wilde, G. J. (1998). Risk homeostasis theory: an overview. Injury Prevention, 4, 89-91. http://dx.doi.org/10.1136/ip.4.2.89

Willamor E, Hammer S, Martinez-Olaizola A. Barriers to bicycle helmet use among Dutch paediatricians. Child Care Health Dev. 2008; 34:743-737.

Zaki, M. H., Sayed, T., \& Cheung, A. (2013). Computer Vision Techniques for the Automated Collection of Cyclist Data. Transportation Research Record (2387), 10-19.

http://dx.doi.org/10.3141/2387-02 
Radun, I., Radun, J., Esmaeilikia, M., \& Lajunen, T. (2018). Risk compensation and bicycle helmets: A false conclusion and uncritical citations. Transportation Research Part F: Traffic Psychology and Behaviour, 58, 548-555. https://doi.org/10.1016/j.trf.2018.06.038

Table I. Studies citing Messiah et al. (2012) study

\begin{tabular}{|c|c|c|c|c|}
\hline Study & $\begin{array}{l}\text { Type of } \\
\text { publicat } \\
\text { ion }\end{array}$ & Direct quotation & Comments & $\begin{array}{l}\text { Was } \\
\text { Messiah } \\
\text { et al. } \\
\text { cited as } \\
\text { evidence } \\
\text { of risk } \\
\text { compens } \\
\text { ation? }\end{array}$ \\
\hline $\begin{array}{l}\text { 1. Billot- } \\
\text { Grasset A } \\
(2015, \mathrm{p} .51)\end{array}$ & $\mathrm{D}$ & $\begin{array}{l}\text { En outre, le phénomène de compensation du risque qui } \\
\text { consiste à prendre plus de risque lors qu'un équipement de } \\
\text { sécurité est utilisé, n'épargne pas les cyclists. La mesure de } \\
\text { ce phénomène est complexe et le consensus reste à ce jour à } \\
\text { construire [ } 80,178] \text {, notamment à cause d'une différence de } \\
\text { comportement entre les hommes et les femmes [152]. } \\
\text { [Unofficial translation: In addition, the phenomenon of risk } \\
\text { compensation, which consists of taking more risk while } \\
\text { utilizing security equipment, does not spare a cyclist. The } \\
\text { measurement of this phenomenon is complex and a } \\
\text { consensus still remains to appear [80,178], especially } \\
\text { because of the behavioral differences between men and }\end{array}$ & $\begin{array}{l}\text { Doctoral dissertation in French. We did } \\
\text { not check the whole text; only identified } \\
\text { one referral based on reference number } \\
{[152] \text {. The text acknowledges }} \\
\text { difficulties in examining risk } \\
\text { compensation, but cites the paper in the } \\
\text { context of risk compensation by } \\
\text { pointing out that there is a difference in } \\
\text { behavior between men and women. }\end{array}$ & yes \\
\hline
\end{tabular}


Radun, I., Radun, J., Esmaeilikia, M., \& Lajunen, T. (2018). Risk compensation and bicycle helmets: A false conclusion and uncritical citations. Transportation Research Part F: Traffic Psychology and Behaviour, 58, 548-555. https://doi.org/10.1016/j.trf.2018.06.038

\begin{tabular}{|c|c|c|c|c|}
\hline & & women ] & & \\
\hline $\begin{array}{l}\text { 2. Félonneau } \\
\text { et al. }(2013 \text {, } \\
\text { p.338) }\end{array}$ & A & $\begin{array}{l}\text { Messiah et al. (2012) identified a risk compensation } \\
\text { phenomenon only among male cyclists: helmeted males } \\
\text { tended to ride faster than those non-helmeted. }\end{array}$ & $\begin{array}{l}\text { Of the six authors of this paper, five } \\
\text { were authors in the original Messiah et } \\
\text { al. study. They cite the study as } \\
\text { evidence of risk compensation. }\end{array}$ & yes \\
\hline $\begin{array}{l}\text { 3. James } \\
(2015 \text {, p. } \\
\text { 253) }\end{array}$ & B & $\begin{array}{l}\text { Risk compensation is a potential, although not inevitable, } \\
\text { consequence whenever preventive measures are undertaken } \\
\text { to improve safety. There is speculation about its possible } \\
\text { occurrence in diverse settings, including road safety (Wilde } \\
\text { et al., 2002), HIV prevention (Cassell et al., 2006), human } \\
\text { papillomavirus vaccination for cervical cancer (Marlow et } \\
\text { al, 2009), and helmet use by skiers and snowboarders } \\
\text { (Sulheim et al., 2006) and cyclists (Fyhri et al., 2012; } \\
\text { Messiah et al., 2012). }\end{array}$ & $\begin{array}{l}\text { A correct citation as the word } \\
\text { "speculation" precedes the reference. }\end{array}$ & no \\
\hline $\begin{array}{l}\text { 4. Kett et al. } \\
(2016 \text {, } \\
\text { p.1161) }\end{array}$ & A & $\begin{array}{l}\text { Much controversy surrounds the implementation of helmet } \\
\text { laws, with opponents citing potential unintended } \\
\text { consequences, including reduced ridership, promotion of the } \\
\text { belief that bicycling is a "dangerous" activity, increased } \\
\text { risk-taking behavior, and diversion of resources away from } \\
\text { infrastructure improvements. While not a consequence of a } \\
\text { helmet law, others believe there is still a lack of solid } \\
\text { evidence documenting the effectiveness of helmets in }\end{array}$ & $\begin{array}{l}\text { It is clear that Kett et al. state that risk } \\
\text { compensation (and other anti-helmet) } \\
\text { "arguments are flawed and have little } \\
\text { evidence to support them"; however, it } \\
\text { is unclear to us whether they, perhaps, } \\
\text { consider Messiah et al.'s study [ref 23] } \\
\text { to be one of the rare studies providing } \\
\text { evidence of (moderate) risk }\end{array}$ & unclear \\
\hline
\end{tabular}


Radun, I., Radun, J., Esmaeilikia, M., \& Lajunen, T. (2018). Risk compensation and bicycle helmets: A false conclusion and uncritical citations. Transportation Research Part F: Traffic Psychology and Behaviour, 58, 548-555. https://doi.org/10.1016/j.trf.2018.06.038

\begin{tabular}{|c|c|c|c|c|}
\hline & & $\begin{array}{l}\text { preventing bicycle-related head injury and so do not } \\
\text { advocate for such legislation }[1,21] \text {. However, as can be } \\
\text { seen by the evidence presented above, as well as numerous } \\
\text { other studies, these arguments are flawed and have little } \\
\text { quality evidence to support them [22-25]. }\end{array}$ & $\begin{array}{l}\text { compensation. Other cited studies [22, } \\
24-25] \text { in this sentence certainly provide } \\
\text { no evidence about risk compensation. }\end{array}$ & \\
\hline $\begin{array}{l}\text { 5. Li et al. } \\
(2014, \text { p.2) }\end{array}$ & $\mathrm{A}$ & $\begin{array}{l}\text { However, helmets as an injury-prevention tool through risk } \\
\text { compensation can lead to behavior changes in cyclists. An } \\
\text { increase in perceived safety can lead cyclists to travel at } \\
\text { higher speeds, which in turn can affect actual safety ( } 22- \\
24) \text {. }\end{array}$ & $\begin{array}{l}\text { Citing the study [22] in connection with } \\
\text { risk compensation by stating that an } \\
\text { increase in perceived safety can lead to } \\
\text { higher speeds. There is nothing in the } \\
\text { original study that would indicate "an } \\
\text { increase in perceived safety." }\end{array}$ & yes \\
\hline $\begin{array}{l}\text { 6. Lundberg } \\
\text { \& Shapira } \\
(2014, \text { p.50) }\end{array}$ & $\mathrm{B}$ & $\begin{array}{l}\text { Risk compensation may differ between men and women; } \\
\text { one study found that speeds increased among male cyclists } \\
\text { but not among female cyclists after the introduction of rules } \\
\text { mandating helmet use (Messiah and others 2012). }\end{array}$ & $\begin{array}{l}\text { Cited as evidence of risk compensation. } \\
\text { We do not know whether wearing } \\
\text { helmets increased speed. Messiah et } \\
\text { al.'s study had nothing to do with "rules } \\
\text { mandating helmet use." }\end{array}$ & yes \\
\hline $\begin{array}{l}\text { 7. Olivier \& } \\
\text { Walter }(2013 \text {, } \\
\text { p. 1) }\end{array}$ & $\mathrm{A}$ & $\begin{array}{l}\text { There is evidence of behaviour modification associated with } \\
\text { helmet wearing in other studies. These have shown that } \\
\text { regular helmet wearers decrease their cycling speed when } \\
\text { not wearing a helmet [3], that male cyclists slightly increase } \\
\text { speed in low speed areas when wearing a helmet [4], } \\
\text { unhelmeted cyclists are more likely to commit a traffic }\end{array}$ & $\begin{array}{l}\text { The cyclists did not increase their speed } \\
\text { [4] as there was no baseline condition. } \\
\text { We do not know whether they increased } \\
\text { their speed and modified their behavior, } \\
\text { we just know that helmeted cyclists } \\
\text { rode faster than unhelmeted cyclists. }\end{array}$ & yes \\
\hline
\end{tabular}


Radun, I., Radun, J., Esmaeilikia, M., \& Lajunen, T. (2018). Risk compensation and bicycle helmets: A false conclusion and uncritical citations. Transportation Research Part F: Traffic Psychology and Behaviour, 58, 548-555. https://doi.org/10.1016/j.trf.2018.06.038

\begin{tabular}{|c|c|c|c|c|}
\hline & & $\begin{array}{l}\text { violation }[5,6] \text { and that some drivers believe helmet wearers } \\
\text { cycling alone may behave more predictably than non-helmet } \\
\text { wearers [7]. }\end{array}$ & & \\
\hline $\begin{array}{l}\text { 8. Olivier \& } \\
\text { Creighton } \\
(2017, \text { p.7) }\end{array}$ & A & $\begin{array}{l}\text { With regards to this review, adjusted summary estimates are } \\
\text { not possible without study-level data on risk compensation, } \\
\text { irrespective of whether the hypothesis is supported by } \\
\text { evidence. For example, Messiah et al }{ }^{83} \text { used average } \\
\text { cycling speed as a measure of risk; however, the speed of } \\
\text { the cyclist at the time of a crash is unknown for every study } \\
\text { included in this review. }\end{array}$ & $\begin{array}{l}\text { A correct and neutral citation [83]. It } \\
\text { simply states the study used cycling } \\
\text { speed as a measure of risk. }\end{array}$ & no \\
\hline $\begin{array}{l}\text { 9. Olivier \& } \\
\text { Terlich } \\
(2016, \text { p.2) }\end{array}$ & $\mathrm{C}$ & $\begin{array}{l}\text { There is no clear evidence supportive of risk compensation } \\
\text { and bicycle helmets and much of the current literature has } \\
\text { been limited to commentaries from authors who are either } \\
\text { supportive or opposed to the hypothesis [5-6]. The very few } \\
\text { real-world studies on risk compensation and bicycle helmets } \\
\text { have used speed as a proxy for risky behavior [7-8]. Neither } \\
\text { study found clear evidence supportive of risk compensation } \\
\text { [9]. }\end{array}$ & $\begin{array}{l}\text { A correct citation [8] stating Messiah et } \\
\text { al.'s study has not found clear evidence } \\
\text { of risk compensation. }\end{array}$ & no \\
\hline $\begin{array}{l}\text { 10. Osorio et } \\
\text { al. (2015, } \\
\text { p.7) }\end{array}$ & $\mathrm{A}$ & $\begin{array}{l}\text { For example, the adoption of health risk-reduction } \\
\text { strategies, such as the use of seat belts, helmets or sunscreen } \\
\text { use, may be partially offset by compensatory behaviours that } \\
\text { increase risk, such as speeding, careless driving or excessive }\end{array}$ & $\begin{array}{l}\text { Cited [30] as evidence of risk } \\
\text { compensation. }\end{array}$ & yes \\
\hline
\end{tabular}


Radun, I., Radun, J., Esmaeilikia, M., \& Lajunen, T. (2018). Risk compensation and bicycle helmets: A false conclusion and uncritical citations. Transportation Research Part F: Traffic Psychology and Behaviour, 58, 548-555. https://doi.org/10.1016/j.trf.2018.06.038

\begin{tabular}{|c|c|c|c|c|}
\hline & & sunbathing.7 830 & & \\
\hline $\begin{array}{l}\text { 11. Peachey, } \\
\text { Sutton, \& } \\
\text { Cathorall } \\
(2016, \text { p.573) }\end{array}$ & A & $\begin{array}{l}\text { Another possible explanation is that those who own a helmet } \\
\text { may believe that they are less susceptible to injury when } \\
\text { they do fall. Risk compensation occurs among male cyclists: } \\
\text { those who wear helmets travel faster (Messiah et al., 2012). }\end{array}$ & Cited as evidence of risk compensation. & yes \\
\hline $\begin{array}{l}\text { 12. Pless } \\
(2016, \text { p.5) }\end{array}$ & A & $\begin{array}{l}\text { Perhaps even more puzzling is one of the few randomized } \\
\text { trials of helmet use in relation to RCT. A study in France by } \\
\text { Messiah and colleagues measured changes in speed } \\
\text { following helmet use adoption. They made } 621 \text { video } \\
\text { recordings of } 587 \text { participants. There were no differences } \\
\text { among the women whereas male cyclists who were } \\
\text { helmeted went } 2.4 \mathrm{~km} / \mathrm{h} \text { faster. The conclusion "Risk } \\
\text { compensation, observed only among male cyclists, was } \\
\text { moderate, thus unlikely to offset helmet preventive } \\
\text { efficacy." [35]. }\end{array}$ & $\begin{array}{l}\text { Although Pless is in general very } \\
\text { critical about risk compensation, he } \\
\text { directly quotes the authors' (false) } \\
\text { conclusion without critical assessment } \\
\text { [35]. Messiah et al.'s study did not } \\
\text { "measure changes in speed following } \\
\text { helmet adoption." }\end{array}$ & yes \\
\hline $\begin{array}{l}\text { 13. Prati, } \\
\text { Pietrantoni, } \\
\text { \& Fraboni } \\
(2017, \text { p.50) }\end{array}$ & A & $\begin{array}{l}\text { Helmet use is lower in male cyclists than female cyclists } \\
\text { (Harlos et al.,1999) and risk compensation has been } \\
\text { observed only among male cyclists as helmeted male } \\
\text { bicyclists tended to ride faster than non-helmeted ones } \\
\text { (Messiah et al., 2012). }\end{array}$ & Cited as evidence of risk compensation. & yes \\
\hline $\begin{array}{l}\text { 14. Richard, } \\
\text { Thélot, \& }\end{array}$ & $\mathrm{A}$ & $\begin{array}{l}\text { On the other hand, in the context of voluntary helmet use, } \\
\text { the main bias results from various existing hypotheses }\end{array}$ & $\begin{array}{l}\text { "Some results suggest... helmets could } \\
\text { encourage risk taking." Cited as }\end{array}$ & yes \\
\hline
\end{tabular}


Radun, I., Radun, J., Esmaeilikia, M., \& Lajunen, T. (2018). Risk compensation and bicycle helmets: A false conclusion and uncritical citations. Transportation Research Part F: Traffic Psychology and Behaviour, 58, 548-555. https://doi.org/10.1016/j.trf.2018.06.038

\begin{tabular}{|c|c|c|c|c|}
\hline $\begin{array}{l}\text { Beck (2013, } \\
\text { p.114) }\end{array}$ & & $\begin{array}{l}\text { concerning the underlying behavioural motivations: some } \\
\text { results suggest that a helmet is more likely to be used by } \\
\text { people learning about health and safety issues, whereas, } \\
\text { contrary to this hypothesis, using a protective device could } \\
\text { encourage risk taking (Lardelli-Claret et al., 2003; Fyhri et } \\
\text { al., 2012; Messiah et al., 2012). }\end{array}$ & evidence of risk compensation. & \\
\hline $\begin{array}{l}\text { 15. Richard, } \\
\text { Thelot, \& } \\
\text { Beck (2013, } \\
\text { p.211) }\end{array}$ & A & $\begin{array}{l}\text { Enfin, certains comportements préventifs ayant depuis } \\
\text { longtemps fait la preuve de leur efficacité, comme l'usage } \\
\text { systématique du casque à vélo [45], se révèlent difficiles à } \\
\text { faire adopter en France [46]. } \\
\text { [Unofficial translation: Finally, certain preventive behaviors } \\
\text { that have long ago proven their efficacy, like the systematic } \\
\text { usage of bicycle helmets, are difficult to get adopted in } \\
\text { France ]. }\end{array}$ & $\begin{array}{l}\text { The citation [46] seems correct as it } \\
\text { mentions the study in terms of the low } \\
\text { prevalence of helmet use. }\end{array}$ & no \\
\hline $\begin{array}{l}\text { 16. Teschke } \\
\text { et al. }(2015 \text {, } \\
\text { p.10) }\end{array}$ & $\mathrm{A}$ & $\begin{array}{l}\text { Others have considered the impact of helmet use on risk- } \\
\text { related behaviours. Such studies are not always consistent, } \\
\text { but some have findings that could help explain our results. } \\
\text { For example, one study found that new male (but not } \\
\text { female) helmet users tended to increase their cycling speed } \\
\text { and one found that drivers approached a cyclist more closely } \\
\text { when he was wearing a helmet.50 } 51\end{array}$ & $\begin{array}{l}\text { Discusses the study [50] in terms of } \\
\text { "the impact of helmet use on risk- } \\
\text { related behavior." The cyclists did not } \\
\text { tend to increase their speed. We do not } \\
\text { know whether they increased their } \\
\text { speed, we just know that helmeted male } \\
\text { cyclists rode faster than unhelmeted }\end{array}$ & yes \\
\hline
\end{tabular}


Radun, I., Radun, J., Esmaeilikia, M., \& Lajunen, T. (2018). Risk compensation and bicycle helmets: A false conclusion and uncritical citations. Transportation Research Part F: Traffic Psychology and Behaviour, 58, 548-555. https://doi.org/10.1016/j.trf.2018.06.038

\begin{tabular}{|c|c|c|c|c|}
\hline & & & cyclists. & \\
\hline $\begin{array}{l}\text { 17. Thomson } \\
\text { \& Carlson } \\
(2015, \text { p.182) }\end{array}$ & A & $\begin{array}{l}\text { Although the research on skiers and snowboarders is } \\
\text { limited, there is support for increased risk taking while } \\
\text { wearing protective equipment in other sports. Higher speeds } \\
\text { were recorded in male cyclists wearing helmets compared to } \\
\text { non-helmet wearing cyclists in an urban setting; although } \\
\text { the difference disappeared at the recording sites with the } \\
\text { highest speeds (Messiah et al., 2012). }\end{array}$ & $\begin{array}{l}\text { Cited as an evidence of increased risk } \\
\text { taking. } \\
\text { Furthermore, we ask whether faster } \\
\text { riding is equal to increased risk taking. }\end{array}$ & yes \\
\hline $\begin{array}{l}\text { 18. Treibich } \\
\text { C (2014, p. } \\
\text { 148) }\end{array}$ & $\mathrm{D}$ & $\begin{array}{l}\text { Messiah et al. (2012) ran a randomized controlled trial in } \\
\text { Bordeaux to analyze motorcyclists' chosen speed } \\
\text { conditional on helmet adoption. Risk compensation was } \\
\text { observed exclusively among men and was of moderate size. } \\
\text { Therefore the feedback effect did not offset the benefits of } \\
\text { helmet use. }\end{array}$ & $\begin{array}{l}\text { Cited as evidence of risk compensation. } \\
\text { Wrongly states that the study examined } \\
\text { the speed of motorcyclists. }\end{array}$ & yes \\
\hline $\begin{array}{l}\text { 19. Zaki, } \\
\text { Sayed, \& } \\
\text { Cheung } \\
(2013, \text { p. 16) }\end{array}$ & A & $\begin{array}{l}\text { Helmet use affected travel speed: cyclists that wore them } \\
\text { tended to travel at higher speeds. This result was consistent } \\
\text { with recently published data that attributed the higher speed } \\
\text { to a false perception of increased safety by those that wore } \\
\text { helmets (26). }\end{array}$ & $\begin{array}{l}\text { A somewhat neutral citation [26] as the } \\
\text { authors shift responsibility for the } \\
\text { conclusions to the original article. } \\
\text { However, they seem to make the same } \\
\text { mistake when making conclusions in } \\
\text { their own study: there is a difference } \\
\text { between observing that helmeted } \\
\text { cyclists ride faster than unhelmeted and }\end{array}$ & yes \\
\hline
\end{tabular}


Radun, I., Radun, J., Esmaeilikia, M., \& Lajunen, T. (2018). Risk compensation and bicycle helmets: A false conclusion and uncritical citations. Transportation Research Part F: Traffic Psychology and Behaviour, 58, 548-555. https://doi.org/10.1016/j.trf.2018.06.038

\begin{tabular}{|l|l|l|l|l|}
\hline & & & $\begin{array}{l}\text { claiming that helmet wearing affects the } \\
\text { riding speed. }\end{array}$ \\
\hline $\begin{array}{l}\text { Sayed, \& } \\
\text { Cheung }\end{array}$ & unclear & $\begin{array}{l}\text { One interesting finding was that helmet usage affects the } \\
\text { travel speed as cyclists with helmets tend to travel at higher } \\
\text { (2013, p. 14) }\end{array}$ & $\begin{array}{l}\text { TRB 2013 Annual Meeting } \\
\text { "Paper revised from original submittal" } \\
\text { data [35], which attributed this difference in the false } \\
\text { perception of increased safety for those utilizing helmets. }\end{array}$ & yes \\
\hline
\end{tabular}

A: article in peer-reviewed journal; B: book chapter; C: peer-reviewed conference proceeding; D: doctoral thesis. 